Linguistik Terapan 16 (1) (2019): 299-314

Jurnal Linguistik Terapan Pascasarjana

Available online

http://jurnal.unimed.ac.id/2019/index.php/JLT-Unimed

\title{
LANGUAGE MAINTENANCE BY JAVANESE FAMILIES IN DESA SAMBIREJO TIMUR
}

\author{
Ayu Utatri Prastica Riadiani \\ English Applied Linguistics Program \\ Postgraduate Program - Universitas Negeri Medan
}

Diterima Desember 2018; Disetujui Februari 2019; Dipublikasikan April 2019

\section{ABSTRACT}

This study deals with language maintenance by Javanese families. It employs qualitative research design with case study. This study aims to find out: (1) the dominant factor affect f Javanese families language maintenance in Desa Sambirejo Timur, (2) the strategies used by Javanese families to maintain their ethnic language, and (3) the reason Javanese families maintained their language. The subjects were ten Javanese families including parents (the third generation) and children in Desa Sambirejo Timur. The instruments used for this study were observation and interview (in-depth interview). The observation was applied to get the data about the factor affect Javanese families' language maintenance. The interview was applied to find the dominant factor affect language maintenance by Javanese families. The data was analyzed by using interactive model from Miles and Huberman's. There are five factors being analyzed, namely: (1) attitude towards Javanese language, (2)value, (3) identity, (4) demography, and social factor. The dominant factor affect Javanese lang8uage maintenance in this study is the attitude towards language. Besides that there is one additional factor found during research namely visiting homeland. The strategy used by parents to maintained Javanese language in their family are: (1) raising Javanese language interest for children by direct them to arts, culture and literature about Javanese such as wayang, Javanese radio broadcasting, and Javanese song and (2) mix Javanese language with Indonesian when speaking to the children.

Key Words : language maintenance, language attitude, family language maintenance, factors in language maintenance

How to Cite: Riadiani.A. U. P. 2019.

Language Maintenance by Javanese Families in Desa Sambirejo Timur. Jurnal Linguistik Terapan Pascasarjana Unimed.16 (1): 299-314

*Corresponding author: ISSN 0216-5139

E-mail: Widyaastuti236@gmail.com 


\section{INTRODUCTION}

Language is not just an instrument for communication but also often an important, even constitutive feature of community's identity, Ferguson (2006:78). The main function of language is as an instrument for communication that links one to another individual, besides that language is a symbol of community's identity and it is part of a community which covers cultural identity. Fishman (1992:4) states that "the destruction of a language is the destruction of a rooted identity". The loss and the destruction of a language are similar with the loss and the destruction of ethnic identity. If a language already destructed then the culture will also be destructed, so that the community will lost their ethnic identity.

Language maintenance is an effort in keeping the language alive by using that language continually in facing the competition among other language in society (Fishman, 1991). A language need to be maintained when the amount of speakers using that language decreases because the young generations prefer to use the dominant language in their society. In other words, language maintenance should be done when that language becomes a minority language in society. Mesthrie (1999:42) defines language maintenance as the continuing use of a language in the face of competition from regionally and socially powerful or numerically stronger language. It is clear that using the language continually in daily communication is one of the ways in maintaining language. By using that language frequently when interact with people with the same language, that language can be developed and preserved.

A language needs to be maintained in order to save identity, for many reasons maintaining and preserving native language is crucial things to do because language is a sign to differentiate one community from other community. For example immigrant ethnic groups who live in a big city should keep using their heritage language when communicating with people from the same ethnic. That is only thing which can be a sign that they are different from other people surrounding and sign that they are people from that ethnic group. More specific example can be drawn from the use of ethnic language among multicultural society in an area for example Javanese people in Medan. Javanese people who live in Medan are immigrant from Java Island. In 1860s, the organized forced emigration from Java began it started with Deli district where Dutch planters had set up tobacco plantation in 1860s. Many Javanese people were sent to Medan as workers in Plantation Company which was governed by the colonial. Javanese people who live in Medan should keep using Javanese language when communicate with people from the same ethnic. In this case Javanese language is the minority language, if Javanese people did not preserve and maintain their language by using the language continually then the language can be endangered.

In this research, Javanese families in the regency of Deli Serdang specifically in the district of Desa Sambirejo Timur were immigrant, moreover in some area they are minority group. Holmes 
(2001:70) cites "the more domain in which minority language is used, the more chances there is to maintain it". Desa Sambirejo Timur is located on the east side of Medan City bordered with Desa Tembung and Bandar Klipah. This area is the boundary area of Medan City and Deli Serdang. The large of Desa Sambirejo Timur are about 429,892 Ha consist of 11 sub-district in Indonesian called as dusun. The profession of the society in Desa Sambirejo Timur are varies, such as civil servant, private employees, seller, construction laborers, and housemaids. Desa Sambirejo Timur was dominated by Javanese, some cultural celebration such as annual event which called as ruwat desa was held. This celebration means purifying the village from disasters as the ancient did. In that event some traditional arts is performed, such as wayang kulit, ludruk, ketoprak and etc. This information is stated by an informant Suyono (75 years old) one of the elder in Desa Sambirejo Timur:

\begin{abstract}
"Sambirejo Timur ini dulunya kebanyakan orang Jawa, kalau sekarang memang sudah banyak pendatang dari suku lain. Penduduk Jawa disini dulu buka lahan bebas yang gak dikuasai sama PTP. Benar-benar Jawa lah kampung ini dulu.Kalau setiap tahun disini selalu buat acara ruwat desa untuk tolak bala, kenduri juga rutin dilakukan disini. Sampai sekarang pun masih ada beberapa kesenian dari Jawa seperti ludruk, wayang kulit, angguk, ketoprak gamelan, tayyiban banyak lah. Tapi semenjak orde baru ini lah yang agak kurang, dulu ada organisasi Lekra (lembaga kebudayaan rakyat) karena dikira komunis jadi organisasi itu dilarang sama pemerintah. Jadi ya gini udah berkurang sekarang, walaupun masih ada tradisi itu disini tapi udah gak sesering jaman dulu”.
\end{abstract}

Based on the statements above, it can be concluded that the use of Javanese cultural arts in that area already decreased. As language and culture is closely related, the destructed of a culture will give impact to the destruction of that language. By the time, people from other ethnic group come to live in that area and the frequency of Javanese language spoken by society is decreased. Thus the writer thought that it is interesting to find out the factors and the dominant factor which affect language maintenance in Desa Sambirejo Timur. Furthur information about this study is explained detailed below.

\title{
Language Maintenance
}

Language maintenance is an effort in keeping the language alive by using that language continually in facing the competition among other language in society (Fishman, 1991). Language society should keep the language alive in order to preserve the language so that the language will not turn into endangered language this because the existence of a language is depend on the effort of the language user. Language maintenance is also a part of language planning, similar to the statement of Kaplan \& Baldauf (1997), "Language maintenance is one of the goals in language planning". Moreover, Musk (2006) argued that in sociolinguistics, the term maintenance generally used to describe a minority language vis-a-vis majority language. It means that language maintenance concern 
with the relation of minority and majority language because the purpose of language maintenance is to keep balance the use of minority and majority language in communication.

Keeping language alive is the objective in the process of language maintenance. Furthermore, Mesthrie (1999:42) defined language maintenance as the continuing use of a language in the face of competition from regionally and socially powerful or numerically stronger language. Thus, in the process of maintaining native language or heritage language parents should keep their attention towards children proficiency in heritage language. If there are only young adults speakers remain and there are no younger children speak that language, then that language is threatened to be endangered.

Hinton (1999) cited in his article that many children have only a passive knowledge of their heritage language. They may reach a point where they understand the home language in a basic way but cannot speak as well as they understand. Others may learn to speak their heritage language fluently but are unable to read and write it. Consequently, those younger speakers will lose their proficiency in heritage language. While the loss of language is close to the loss of cultural identity, it could threaten the community's identity and culture.

This argument is supported by a strength statement from Fishman (1991) in Ferguson, "the destruction of a language is the destruction of rooted identity". It is clear that language maintenance is important effort to prevent language loss and the loss of ethnic identity. In maintaining a language, the community should aware of the important of language maintenance for their language holding on to that language and concerning to the process of language maintenance.

\section{Factors Affecting Language Maintenance}

\section{a. Internal Factors in Language Maintenance}

(1) Attitude towards ethnic language

Attitude towards language is the feelings people have about their own language. Attitude is important notion in study of language maintenance. Language attitude could be defined as psychological of an individual towards a language. Ethnic groups usually distinguish itself by its language and cultural norm. The identity and pride of an ethnic group is expressed through its ethnic/heritage language.Holmes (1992) expressed three levels of attitudes towards a social or ethnic group; (1) attitudes towards a social or ethnic group, (2) attitudes towards the language, and (3) attitudes towards individual speakers of that language. Attitude towards the language reflects attitude towards an ethnic group and how the individual of an ethnic group regard their cultural heritage. For instance children attitude towards their ethnic language related to how they regard their own culture. Children who have negative attitude towards their cultural heritage will also have low value towards their ethnic language.There are two kinds of attitude towards language there are positive and negative attitude. Positive attitude towards the language results high value and motivation to maintain the 
language, thus it motivates speakers to use ethnic language continually.Negative attitude results low value and motivation to maintain the language so that it causes speakers reluctant to use the ethnic language.

(2) Value

Values is the act of regarding and appreciating language and cultural as heritage of a community. Holmes (2002) pointed out that when the speakers have high value of the language and the language is seen as the symbol of ethnic identity, the languages will be maintained by the speakers. When the language is valued and regarded with pride as identifier of minority group and expressing its distinctive culture, there is more chance to maintain it.Attitude and value are the crucial factors which affect the process oflanguage maintenance. Sharples (2010) defined attitude, value and beliefs as: (1) attitudes is the opinion towards specific aspect of language use in society as its role, it can be referred as positive, negative or neutral; (2) values is the general underlying orientation of an individual towards a language and ultimately towards the speakers of that language; (3) beliefs is knowledge about a language and the people that speak the language.

(3) Identity

Language is also use as a marker of our membership in social groups. Several of social group membership, along with the values, beliefs and attitudes associated with them, are significant to the development of social identities. The maintenance of ethnic identity is closely related to the role of ethnic language in daily life. Social group member may discard their ethnic language or they may preserve it as a sign of ethnic identity. It is mostly happen in immigrants social group member where their ethnic language is competes with dominant language. As Fishman (1989) argued the culture and language of the native group among children of immigrants tend to weaken with each new generation.

\section{b. External Factors in Language Maintenance}

(1) In the case of demographic, the number of population who speak that language affect the maintenance of the language itself. Gibson \& Ramirez (2004:66) state that the greater the number of speakers of a language, the greater is the probability that this language will be maintained, transmitted and learned.Ifan ethnic group moves to another area dominated by majority of other ethnic group and the minority ethnic group still use their heritage continually in some domains, that language is maintained by the minority speakers. In contrast, if an ethnic group moves to another area dominated by majority of other ethnic group and they use national language rather than heritage language to communicate within that group, then the language will faces its loss and need to be maintained. Speakers who speak heritage or native language as their second language may have low and high proficiency of that language which influence by the role of family and the environment. If they live 
surrounding people with the same ethnic and use the same heritage language then they will have high proficiency in heritage language.

(2) The economic development is also affects the progress of heritage language maintenance. People who seek a job are forced to master the language which is used in economic domain; consequently the minority language is spoken less continually as the result the language is less maintained. This is caused by people thought that it is no necessary to learn heritage language, because it could not earn money. On the other hand, educated generation start preferring learn foreign language because they assume that acquiring and mastering that language could earn more money.

(3) The social factors, language are considered as an important symbol of minority or majority group's identity. The tendency to shift the minority language to the majority language occurs when people are anxious to involve in a society where knowledge of the second language is pre-requisite for success. As the result, minority language could be maintained if language society has positive attitude and high value towards their language.

\section{Language Maintenance in Family}

Family holds important role in the process of language maintenance. Family is the domain where children's language development especially for heritage or native language occurs. The intimacy in family domain could be natural boundary to against outside pressures. The majority language in school area could be one of the outside pressures which may attacts the development of children's ethnic language proficiency. In order to prevent the outside pressure parents should control children language development. Besides, the other family members such as siblings also give impact to the children language development. The older children who act as mediator to the younger's language development are more experience in acquiring ethnic language will share the knowledge through the interaction with the younger. On the other hand, older children who acquire more majority language and bring it into the home will speak that language to their parents and their younger's siblings. Spolsky (2007) argued that the older children bring the majority language into the home and speak it occasionally with parents and regularly with younger siblings. Children may feel less positive attitude towards their heritage or ethnic language when they take part in school activities and become assimilated into dominant language society.

The way family and society group maintaining their language is varies from one to another. For instance parent could keep using heritage language in communication with the family member so that their children accustomed with that heritage language.Besides that, take children visiting their homeland and attending the ethnic ceremonial will also raise their curiosity about their culture and their heritage language. Moreover, family decision to choose whether national or heritage language in the home domain communication give significant benefit to the maintenance of heritage language. 
However parents will have their own way to lead the children to regard ethnic language. For instance, parent's value towards Javanese language could be seen as they assume that Javanese language is related to their culture identity which is the precious thing and they consider that it connects younger generation to their home land and culture. Another way that could be done by parents is by strengthen the knowledge to children about Javanese language as their ethnic language, that it is crucial to be maintained because this language is necessary link the family that reinforces family ties. When Javanese family gathering with the family and using their language, it will increase the intimacy among the family members.

\section{RELEVANT STUDIES}

Language maintenance has been investigated in various researches by some experts. Some previous researches showed that language maintenance are affected by the role of family and the attitude of language users towards its language. Since one aspect of language attitude is behavior (Garret. Et.al. 2003), it means that language attitude will create language behavior, and then positive language attitude will also create positive language behavior.Lukman(2000) did a research about language maintenance of Javanese immigrant society in Wonomulyo, Polmas. The finding of that research shows that generally the society in Java island speak bilingually and tend to use their ethnic language in some domain such as family, neighborhood, and occupation. Zhang (2004) examines the attitudes about home language maintenance among Chinese American children and their parents. $\mathrm{He}$ explores (1) the extent to which participants believe home language has been maintained by the Chinese children who are born in first-generation immigrants families, and (2) what factors are involved in ptomoting the children's home language maintenance. His analysis indicates thatChinese parent's strong commitement to home language maintenance, most second generation Chinese children do maintain the home language to a certain degree, but they show preference for shift to English in key social context from an early age. His research finding strengthen the theories from some expert that family is key instrument in language maintenance process. Besides that, his research also enrich the new horizon in the field of language maintenance in family. Another research was conducted by Verdon, et.all (2014) about "Language Maintenance and Loss in a Population Study of Young Australian Children". In that research, they attempt to identify the patterns of language acquisition, maintenance, and loss that are occurring among Australian children during early childhood. They determine the problem as: (1) What patterns of language use, maintenance, and loss are occur-ring within multilingual children and among the most common language-minority communities in Australia duringearly child-hood?, (2) What personal and environmental factors (including gender, languages spoken by parents, presence of a grandparent or older sibling in the home, being a first- or second-generation immigrant, type of childcare and support for languages other than English in the learning environment) are associated with patterns of language use, maintenance, and loss in Australian multilingual children?. The finding of their research shows that 
parental use of a language other than English was highly correlated with children speaking languages other than English.From those relevant studies, it can be concluded that family is the key point of the process in maintaining language. Parents' encouragement to use Javanese language will rise children's motivation to use Javanese language in daily communication. However, the whole family members' attitude towards Javanese language will also give an impact to the sustainability and vitality of language maintenance in family.

\section{METHODOLOGY}

This study was conducted in qualitative research design with descriptive case study which described the factors affect language maintenance in Javanese families. Data of this study were the transcription of interviews and recorded observation. The instruments of data collection were: 1) interview and 2) participant observation. The writer did participant observation and in-depth interviews to get the empirical evidence. Tape recorder was used to record the conversation whichmade during the data collection; the data which cannot be interviewed were taken by field notes. The data of this study were listed as follows: 1) transcription of participant observation, 2) field notes taken during the observation, 3) transcription of interview, and 4) field notes during the interview.The subjects of this study were 10 Javanese families who live in Desa Sambirejo Timur. The criteria of the subjects were as follows:

1) The member of the families are able to speak Bahasa Indonesia fluently

2) They live in the region of Desa Sambirejo Timur, Kecamatan Percut Sei Tuan

3) The parents are third generation of the ethnic group

4) Children of Javanese families

The data analysis is the process of systematically arranging the interview transcript, questionnaires and field notes to support the research, the data of this research will be gathered in words. Data analysis of this research was done by applying interactive model from Miles and Huberman (1994), it was done in three steps; (a) data reduction, (b) data display, and (c) data conclusion. In data reduction, the data were selected based on the criteria of the data, namely the statements that showing the factors affecting families' language maintenance in Desa Sambirejo Timur. Then in data display, the statements which showing language maintenance were placed in the form of table and will be classified based on the factors. Finally the data were concluded whether there were other factors that could be found which may affect language maintenance and the most dominant factors which affect language maintenance in Javanese families.

The Categorization Based on The Factors Affect Language Maintenance

Table 4.1 Attitude towards language

\begin{tabular}{|c|c|c|c|}
\hline No. & Family & Parent & Children \\
\hline
\end{tabular}




\begin{tabular}{|c|c|c|c|}
\hline 1. & 1 & $\begin{array}{l}\text { Ya karena agak susah nanti anak-anak } \\
\text { menyesuaikan diri sama teman-temannya } \\
\text { disekolah kalau terbiasa pakai bahasa } \\
\text { Jawa. }\end{array}$ & $\begin{array}{l}\text { Iya. Soalnya bahasa Jawa kan Cuma } \\
\text { bahasa daerah. }\end{array}$ \\
\hline 2. & 2 & $\begin{array}{l}\text { Sering, apalagi kalau keluarga kumpul } \\
\text { dirumah. Neneknya juga selalu pakai } \\
\text { bahasa Jawa sama anak-anak. }\end{array}$ & $\begin{array}{l}\text { Kalau sama abang pakai bahasa } \\
\text { Indonesia, tapi kalau bicara sama orang } \\
\text { tua kadang dicampur, Jawa sama } \\
\text { Indonesia terkadang juga kalau sama } \\
\text { temen yang sama-sama orang Jawa juga } \\
\text { pakai bahasa Jawa sih. }\end{array}$ \\
\hline 3. & 3 & $\begin{array}{l}\text { Ya enggak lha, kan kalau sudah sekolah } \\
\text { juga gurunya ngajarin bahasa Indonesia. } \\
\text { Ya dirumah sama orang tua ya harus } \\
\text { bahasa Jawa lah. }\end{array}$ & $\begin{array}{l}\text { Penting ya bahasa Jawa penting lah. } \\
\text { Karena temen-temen disekolah Juga } \\
\text { banyak yang pakai bahasa Jawa. }\end{array}$ \\
\hline 4. & 4 & $\begin{array}{l}\text { Penting ya gimana ya, kek mana ya ya } \\
\text { bahasa Indonesia aja la, gak pake bahasa } \\
\text { Jawa udah gapapa lah. }\end{array}$ & $\begin{array}{l}\text { Enggak lah, buat apa sih malu kalau } \\
\text { memang tau bahasa Jawa buat apa } \\
\text { dipendam-pendam. }\end{array}$ \\
\hline 5. & 5 & $\begin{array}{l}\text { Harus sih maunya, karena ya } \\
\text { bagaimanapun orang jawa ya harus } \\
\text { menguasai bahasa Jawanya. }\end{array}$ & Enggak malu kok. \\
\hline 6. & 6 & $\begin{array}{l}\text { Ya kalau lawan bicara nya orang Jawa ya } \\
\text { lebih milih bahasa Jawa lah. }\end{array}$ & $\begin{array}{l}\text { Ya lebih simpel, lebih enak ketimbang } \\
\text { bahasa Indonesia. Disekolah juga sama } \\
\text { kawan-kawan yang orang Jawa pakai } \\
\text { bahasa Jawa juga. }\end{array}$ \\
\hline 7. & 7 & $\begin{array}{l}\text { Kalau dirumah ya sering, kalau ngomong } \\
\text { sama keluarga dirumah ya ngomong Jawa. }\end{array}$ & $\begin{array}{l}\text { Ya penting la untuk melestarikan } \\
\text { sukunya sendiri juga. }\end{array}$ \\
\hline 8. & 8 & $\begin{array}{l}\text { Dua-duanya utama lah, bahasa Indonesia } \\
\text { juga penting kan orang Indonesia harus } \\
\text { juga lancar bahasa Indonesia. Tapi kalau } \\
\text { ibu ngomong sama orang Jawa ya ibu } \\
\text { milih bahasa Jawa, lebih enak udah. }\end{array}$ & $\begin{array}{l}\text { Karena ya memang dari adatnya aja } \\
\text { dari Jawa. }\end{array}$ \\
\hline 9. & 9 & $\begin{array}{l}\text { Yaa kita ini orang Jawanya, orang tua itu } \\
\text { nurunkan sama anaknya budaya Jawa itu } \\
\text { kalau bahasa Jawa itu ya wajib dipahami } \\
\text { sama orang Jawa supaya gak ilang } \\
\text { bahasanya. }\end{array}$ & $\begin{array}{l}\text { Misalnya ngomong sama temen pakai } \\
\text { bahasa Indonesia, sama orag tua bahasa } \\
\text { Jawa. }\end{array}$ \\
\hline 10. & 10 & $\begin{array}{l}\text { Kalau bicara sama istri kadang-kadang } \\
\text { pakai bahasa Jawa. }\end{array}$ & Enggak malu sih. \\
\hline
\end{tabular}

Table 4.2 Language value

\begin{tabular}{|c|c|c|c|}
\hline No. & Family & Parent & Children \\
\hline 1. & 1 & $\begin{array}{l}\text { Ya perlu sih, tapi untuk yang paham saja } \\
\text { tidak harus dipaksakan wajib mempelajari } \\
\text { bahasa jawa itu. }\end{array}$ & $\begin{array}{l}\text { Ya penting kalau sesama orang yang } \\
\text { sesuku. Tapi kan disekolah juga wajib } \\
\text { pakai bahasa Indonesia, kalau cari kerja } \\
\text { juga enggak ditanya bisa bahasa daerah } \\
\text { atau enggak. }\end{array}$ \\
\hline 2. & 2 & $\begin{array}{l}\text { Nah seperti yang saya bilang tadi, saya } \\
\text { selalu ingatkan anak-anak untuk pakai } \\
\text { bahasa Jawa dirumah walaupun dicampur } \\
\text { dengan bahasa Indonesia ya gak masalah, } \\
\text { yang penting masih tetap terbiasa pakai } \\
\text { bahasa Jawa. Kalau ada acara kumpul } \\
\text { keluarga besar juga keluarga saya } \\
\text { bicaranya pakai bahasa Jawa kok. }\end{array}$ & $\begin{array}{l}\text { Enggak ada, cuek aja sih kan memang } \\
\text { orang Jawa jadi wajar aja kan pakai } \\
\text { keceplosan bahasa Jawa. }\end{array}$ \\
\hline 3. & 3 & Kita kasi contoh aja sama anak-anak & - \\
\hline
\end{tabular}




\begin{tabular}{|c|c|c|c|}
\hline & & $\begin{array}{l}\text { kalau dirumah ya pakai bahasa Jawa gitu, } \\
\text { nah kalau pulang kampung ke Jawa juga } \\
\text { otomatis anak-anak saya itu lebih fasih } \\
\text { kadang logat Jawanya, sampai terbawa } \\
\text { pulang ke Medan logat Jawa nya itu. }\end{array}$ & \\
\hline 4. & 4 & $\begin{array}{l}\text { Ya enggak la anaknya ya diajarin bahasa } \\
\text { Indonesia cuma kan kebiasaan kek gitu } \\
\text { ngomongnya ya ada yang bahasa } \\
\text { Indonesia ada yang ngomong Jawa jadi } \\
\text { kan gak bisa di pastikan kali kan. }\end{array}$ & $\begin{array}{l}\text { Bahasa Indonesia sih, karena adek juga } \\
\text { gak paham bahasa Jawa. }\end{array}$ \\
\hline 5. & 5 & $\begin{array}{l}\text { Diajarin nya sih enggak langsung gitu, } \\
\text { tapi sering diselipkan bahasa Jawa aja } \\
\text { kalau saya bicara dengan anak-anak. }\end{array}$ & $\begin{array}{l}\text { Paham, tapi kalau saya ngomong Jawa } \\
\text { gak lancar. }\end{array}$ \\
\hline 6. $\mathrm{g}$ & 6 & $\begin{array}{l}\text { Sering diajakin ngomong Jawa sama } \\
\text { bapaknya, saya juga suka putar itu radio } \\
\text { Jawa, kan ada juga di Medan ini. Sampai } \\
\text { sekarang juga, siarannya itu bahasa Jawa, } \\
\text { lagu-lagu Jawa gitu jadi terbiasa anak- } \\
\text { anak itu kan, jadi fasih dia. Disini pun } \\
\text { tetangga saya orang Jawa juga pada } \\
\text { ngomong Jawa juga, ya jadi udah enak } \\
\text { aja. }\end{array}$ & $\begin{array}{l}\text { Diajarinnya sih enggak, tapi dibiasakan } \\
\text { aja dari kecil. Kawan-kawan main disini } \\
\text { juga nganggo bahasa Jawa. Jadi wes } \\
\text { kebiasaan aja. Sampe sekarang mamak } \\
\text { juga masih ngomong Jawa sama aku. }\end{array}$ \\
\hline 7. & 7 & $\begin{array}{l}\text { Kalau saya sih ya itu ngajak anak-anak } \\
\text { ngomong Jawa aja, jadi anak-anak juga } \\
\text { ngerti kalau yang sopan itu ya ngomong } \\
\text { Jawa sama orang tua, lebih sopan lah } \\
\text { gitu. }\end{array}$ & $\begin{array}{l}\text { Bahasa Jawa juga, sama tetangga yang } \\
\text { kadang pakau bahasa Jawa kadang } \\
\text { bahasa Indonesia. }\end{array}$ \\
\hline 8. & 8 & $\begin{array}{l}\text { Sering juga, anak saya ngomong Jawa } \\
\text { juga dirumah. Apalagi kalau pulang } \\
\text { kampung, sama neneknya harus ngomong } \\
\text { Jawa. }\end{array}$ & Sering sih ngomong Jawa. \\
\hline 9. & 9 & $\begin{array}{l}\text { Upayanya tetap terus membimbing anak- } \\
\text { anak supaya tetap ingat sama tradisinya } \\
\text { supaya gak lupa kalau mereka orang } \\
\text { Jawa, makanya saya mesti itu dirumah } \\
\text { ngomong Jawa sama anak istri saya. }\end{array}$ & $\begin{array}{l}\text { Iya, memang udah tradisi dari kecil } \\
\text { dirumah pakai bahasa Jawa. }\end{array}$ \\
\hline 10 . & 10 & $\begin{array}{l}\text { Bahasa Indonesia saja lah supaya lebih } \\
\text { gampang bersosialisasi dengan orang, } \\
\text { lagian kan kita gak tinggal di Jawa. }\end{array}$ & $\begin{array}{l}\text { Enggak terbiasa, bahasa Jawa itu susah } \\
\text { diartikan. }\end{array}$ \\
\hline
\end{tabular}

Table 4.3 Identity

\begin{tabular}{|c|c|c|c|}
\hline No. & Family & Parent & Children \\
\hline 1. & 1 & $\begin{array}{l}\text { Ya bahasa jawa itu bahasa lokal, sesama } \\
\text { orang jawa yang paham ya boleh pakai } \\
\text { bahasa jawa. }\end{array}$ & - \\
\hline 2. & 2 & - & $\begin{array}{l}\text { Ya karena kan kami orang Jawa, udah } \\
\text { dibiasakan sama ayah dari kecil pakai } \\
\text { bahasa Jawa. }\end{array}$ \\
\hline 3. & 3 & Lah harus bisa, orang Jawa kok. & $\begin{array}{l}\text { Lah kok malu, orang Jawa ya pakai } \\
\text { bahasa Jawa lah. }\end{array}$ \\
\hline 4. & 4 & $\begin{array}{l}\text { Ya enggak la anaknya ya diajarin bahasa } \\
\text { Indonesia cuma kan kebiasaan kek gitu } \\
\text { ngomongnya ya ada yang bahasa } \\
\text { Indonesia ada yang ngomong Jawa jadi } \\
\text { kan gak bisa di pastikan kali kan. }\end{array}$ & $\begin{array}{l}\text { Ya kalau bahasa Jawa buat orang jawa } \\
\text { ya penting, masa sih orang Jawa gak tau } \\
\text { bahasa Jawa itu gimana. }\end{array}$ \\
\hline
\end{tabular}




\begin{tabular}{|c|c|c|c|}
\hline 5. & 5 & $\begin{array}{l}\text { Ya penting juga kan bahasa Jawa itu } \\
\text { bahasa nya orang Jawa, ya orang tau } \\
\text { kalau kita orang Jawa kan kalau kita } \\
\text { ngomong Jawa gitu. }\end{array}$ & - \\
\hline 6. & 6 & $\begin{array}{l}\text { O ya jelas la orang Jawa nya itu sendiri, } \\
\text { suku Jawa ya harus tetap menjaga adat } \\
\text { Jawa bahasa Jawa nya itu. }\end{array}$ & - \\
\hline 7. & 7 & $\begin{array}{l}\text { Orang Jawa nya itu lah, tradisis-tradisi } \\
\text { Jawa itu terus dipertahankan maunya. }\end{array}$ & $\begin{array}{l}\text { Kenapa harus malu wong itu kan suku } \\
\text { nya sendiri. }\end{array}$ \\
\hline 8. & 8 & $\begin{array}{l}\text { Kalau ibu sih mau dimana pun kalau sama } \\
\text { anak ya sama suami tetap ngomong Jawa } \\
\text { ya namanya kita orang Jawa ya ngomong } \\
\text { Jawa lah. }\end{array}$ & $\begin{array}{l}\text { Penting karena perkumpulan kita orang } \\
\text { Jawa jadi belajar bahasa Jawa ya } \\
\text { penting }\end{array}$ \\
\hline 9. & 9 & $\begin{array}{l}\text { Yaa kita ini orang Jawanya, orang tua itu } \\
\text { nurunkan sama anaknya budaya Jawa itu } \\
\text { kalau bahasa Jawa itu ya wajib dipahami } \\
\text { sama orang Jawa supaya gak hilang } \\
\text { bahasanya. }\end{array}$ & $\begin{array}{l}\text { Sebagian dari pemuda-pemudi suku } \\
\text { Jawanya. }\end{array}$ \\
\hline 10. & 10 & - & - \\
\hline
\end{tabular}

Table 4.4 Demography

\begin{tabular}{|c|c|c|c|}
\hline No. & Family & Parent & Children \\
\hline 1. & 1 & $\begin{array}{l}\text { Iya karena anak-anak gak bisa bahasa } \\
\text { jawa, cuma saya dan istri yang bisa. Dulu } \\
\text { sebelum pindah kesini kan tinggalnya } \\
\text { bukan di lingkungan jawa seperti disini, } \\
\text { jadi anak-anak gak terlalu sering } \\
\text { mendengar bahasa jawa. Tapi ya kalau } \\
\text { sedikit-sedikit ngerti mereka, kalau bicara } \\
\text { yang gak bisa. }\end{array}$ & - \\
\hline 2. & 2 & $\begin{array}{l}\text { Sudah lama. Orang tua saya asli sini. Jadi } \\
\text { dari lahir saya sudah disni. }\end{array}$ & - \\
\hline 3. & 3 & $\begin{array}{l}\text { Bisa la wong saya orang Jawa, saya lahir } \\
\text { di Jogja sejak menikah baru pindah ke } \\
\text { Medan. }\end{array}$ & - \\
\hline 4. & 4 & Ibu dari Jawa, bapak yang orang Dolok & - \\
\hline 5. & 5 & $\begin{array}{l}\text { Sudah, orang tua saya asli sini jadi dari } \\
\text { lahir sudah tinggal disini. }\end{array}$ & - \\
\hline 6. & 6 & 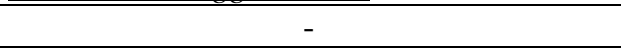 & - \\
\hline 7. & 7 & - & - \\
\hline 8. & 8 & Saya pindahan dari Surabaya. & - \\
\hline 9. & 9 & - & - \\
\hline 10. & 10 & - & - \\
\hline
\end{tabular}

Table 4.5 Social factor

\begin{tabular}{|l|l|c|c|}
\hline No. & Family & Parent & \multicolumn{1}{c|}{ Children } \\
\hline 1. & 1 & - & - \\
\hline 2. & 2 & - & $\begin{array}{l}\text { Sering juga apalagi tetangga kanan kiri } \\
\text { orang Jawa, yaudah pakai bahasa Jawa } \\
\text { lah jadinya. }\end{array}$ \\
\hline 3. & 3 & - & - \\
\hline 4. & 4 & - & - \\
\hline 5. & 5 & - & \\
\hline
\end{tabular}




\begin{tabular}{|l|l|l|l|}
\hline 6. & 6 & $\begin{array}{l}\text { tetangga saya kanan kiri anaknya pada } \\
\text { masih bisa fasih ngomong Jawa nya }\end{array}$ & $\begin{array}{l}\text { Diajarinnya sih enggak, tapi dibiasakan } \\
\text { aja dari kecil. Kawan-kawan main disini } \\
\text { juga nganggo bahasa Jawa. Jadi wes } \\
\text { kebiasaan aja. Sampe sekarang mamak } \\
\text { juga masih ngomong Jawa sama aku. }\end{array}$ \\
\hline 7. & 7 & $\begin{array}{l}\text { Kalau saya sih pilih bahasa Jawa, karena } \\
\text { disini banyak orang Jawa juga jadi lebih } \\
\text { sering bahasa Jawa. }\end{array}$ & $\begin{array}{l}\text { Karena udah terbiasa dari kecil diajarin } \\
\text { bahasa Jawa, kadang disekolah sama } \\
\text { temen deket juga pakai bahasa Jawa. }\end{array}$ \\
\hline 8. & 8 & $\begin{array}{l}\text { Bahasa Jawa, anak saya dulu kecilnya } \\
\text { juga di Surabaya jadi disana sudah } \\
\text { terbiasa sama teman-teman disekitar } \\
\text { rumah itu bahasa Jawa. Sampai pindah } \\
\text { kesini ya masih tetap ngomong Jawa }\end{array}$ & $\begin{array}{l}\text { Sama tetangga yang orang Jawa ya } \\
\text { pakahasa Jawa. }\end{array}$ \\
\hline 9. & 9 & $\begin{array}{l}\text { Iya fasihlah udah kebiasaan dari. Dulu } \\
\text { anak-anak kecil disini fasih-fasih ngomong } \\
\text { Jawanya. }\end{array}$ & \\
\hline 10. & 10 & $\begin{array}{l}\text { Dulu juga tetangganya bukan orang Jawa, } \\
\text { jadi gak terbiasa mungkin. }\end{array}$ & \\
\hline
\end{tabular}

There is additional factor influence the maintenance of Javanese language family in Desa Sambirejo Timur namely visiting homeland. The statement found in family 3 (“...nah kalau pulang kampung ke Jawa juga otomatis anak-anak saya itu lebih fasih kadang logat Jawanya, sampai terbawa pulang ke Medan logat Jawa nya itu.")* and statement from family 8 ("Apalagi kalau pulang kampung, sama neneknya harus ngomong Jawa.")* reveal that the awareness and the willingness to speak Javanese language raised when they visited their homeland, moreover the society in their homeland frequently speaking this language.

Table 4.6 Language Maintenance by Javanese Families in Desa Sambirejo Timur

\begin{tabular}{|c|c|c|c|c|c|c|c|c|c|c|c|c|c|}
\hline \multirow[t]{2}{*}{ No } & \multirow[t]{2}{*}{ Family } & \multicolumn{2}{|c|}{ Attitude } & \multicolumn{2}{|c|}{ Value } & \multicolumn{2}{|c|}{ Identity } & \multicolumn{2}{|c|}{$\begin{array}{c}\text { Demograp } \\
\text { hy }\end{array}$} & \multicolumn{2}{|c|}{ Social } & \multicolumn{2}{|c|}{$\begin{array}{l}\text { Visiting } \\
\text { Homeland }\end{array}$} \\
\hline & & $\mathbf{P}$ & $\mathbf{C}$ & $\mathbf{P}$ & $\mathbf{C}$ & $\mathbf{P}$ & $\mathbf{C}$ & $\mathbf{P}$ & $\mathbf{C}$ & $\mathbf{P}$ & $\mathbf{C}$ & $\mathbf{P}$ & $\mathrm{C}$ \\
\hline 1. & 1 & $\sqrt{ }$ & $\sqrt{ }$ & $\sqrt{ }$ & $\sqrt{ }$ & $\sqrt{ }$ & - & $\sqrt{ }$ & - & - & - & - & - \\
\hline 2. & 2 & $\sqrt{ }$ & $\sqrt{ }$ & $\sqrt{ }$ & $\sqrt{ }$ & - & $\sqrt{ }$ & $\sqrt{ }$ & - & - & $\sqrt{ }$ & - & - \\
\hline 3. & 3 & $\sqrt{ }$ & $\sqrt{ }$ & $\sqrt{ }$ & - & $\sqrt{ }$ & $\sqrt{ }$ & $\sqrt{ }$ & - & - & $\sqrt{ }$ & $\sqrt{ }$ & - \\
\hline 4. & 4 & $\sqrt{ }$ & $\sqrt{ }$ & $\sqrt{ }$ & $\sqrt{ }$ & $\sqrt{ }$ & $\sqrt{ }$ & $\sqrt{ }$ & - & - & - & - & - \\
\hline 5. & 5 & $\sqrt{ }$ & $\sqrt{ }$ & $\sqrt{ }$ & $\sqrt{ }$ & $\sqrt{ }$ & - & $\sqrt{ }$ & - & - & - & - & - \\
\hline 6. & 6 & $\sqrt{ }$ & $\sqrt{ }$ & $\sqrt{ }$ & $\sqrt{ }$ & $\sqrt{ }$ & - & - & - & $\sqrt{ }$ & $\sqrt{ }$ & - & - \\
\hline 7. & 7 & $\sqrt{ }$ & $\sqrt{ }$ & $\sqrt{ }$ & $\sqrt{ }$ & $\sqrt{ }$ & $\sqrt{ }$ & - & - & $\sqrt{ }$ & $\sqrt{ }$ & - & - \\
\hline 8. & 8 & $\sqrt{ }$ & $\sqrt{ }$ & $\sqrt{ }$ & $\sqrt{ }$ & $\sqrt{ }$ & $\sqrt{ }$ & $\sqrt{ }$ & - & $\sqrt{ }$ & $\sqrt{ }$ & $\sqrt{ }$ & - \\
\hline 9. & 9 & $\sqrt{ }$ & $\sqrt{ }$ & $\sqrt{ }$ & $\sqrt{ }$ & $\sqrt{ }$ & $\sqrt{ }$ & - & - & $\sqrt{ }$ & - & - & - \\
\hline 10. & 10 & $\sqrt{ }$ & $\sqrt{ }$ & $\sqrt{ }$ & $\sqrt{ }$ & - & - & - & - & $\sqrt{ }$ & - & - & - \\
\hline \multirow{2}{*}{\multicolumn{2}{|c|}{ Total }} & 10 & 10 & 10 & 9 & 8 & 6 & 6 & 0 & 5 & 5 & 2 & 0 \\
\hline & & \multicolumn{2}{|c|}{20} & \multicolumn{2}{|c|}{10} & \multicolumn{2}{|c|}{17} & & \multicolumn{2}{|c|}{10} & \multicolumn{2}{|c|}{2} \\
\hline
\end{tabular}

Note $\quad: \mathrm{P}$ (parent), $\mathrm{C}$ (children) 
From the table above it could be concluded that the attitude towards language is the most dominant factor which affect family language maintenance in Desa Sambirejo Timur. The attitude towards language refers to the prejudice and the opinion as the reaction towards a language. The feelings and the opinion about Javanese language in family influence the preservation of this language. Furthermore the attitude towards Javanese language also reflects the attitude towards Javanese ethnic group and Javanese cultural heritage. Thus when a group of Javanese society concern and regard about their culture, they also maintain their Javanese language.

\section{FINDINGS}

Based on analysis 4.2 on the previous pages the findings are the following:

1. The factors which affect language maintenance in Javanese families in Desa Sambirejo Timur are varies, namely; (1) attitude towards Javanese language, (2) value on Javanese language, (3) identity of the society, (4) demography, (5) social factor and (6)visiting homeland. The most dominant factors which affect family language maintenance in this research isthe attitude towards language. Parent's attitude to Javanese language influence children ability in speaking Javanese because the motivation from parents and other family member are needed in maintaining ethnic language in a family.

2. Each Javanese family in Desa Sambirejo Timur have different strategy to maintain this ethnic language some of them decided to choose Javanese as their home language so that the vitality of this language is preserved. Parents' motivation and direction in preserving Javanese language also crucial to maintain this language. Parents raising Javanese language interest for children by direct them to arts, culture and literature about Javanese such as wayang, Javanese radio broadcasting, and Javanese song. Some parents also aim to mix Javanese language with Indonesian when speaking to their children.

3. The opinions, ideas and prejudices about ethnic language defined the sustainable of Javanese language in families. Javanese families in Desa Sambirejo Timur assume that maintaining their ethnic language as their responsibility. They maintain Javanese language because they thought the preservation of ethnic language and culture are crucial. As Javanese ethnic society, they responsible to the maintenance and preservation of their ethnic language.

\section{Discussion}

In this research there are six factors affect Javanese families language maintenance in Desa Sambirejo Timur, namely attitude towards Javanese language, value on Javanese language, identity, demography, social factor, and visiting homeland. The most dominant factor affects is attitude towards Javanese language. There is the additional factor found during the research namely visiting homeland. When Javanese families make tripback to their homeland they are interacting with the 
relatives with the same ethnic moreover they are motivated to speak Javanese which resulting the strengthen of ability to speak Javanese language. Hence the frequently ethnic group visit their homeland affect the maintenance of ethnic language. One of the way for immigrant families to continually use their ethnic language and inherit their ethnic language to the descendant is motivate them by visiting homeland where the intimacy among the family member could support the attitude towards their ethnic language.

The strategies to maintain Javanese language found in this research is varies, children in some families learn Javanese language since the early age and they speak Javanese with the neighborhood. In other family, Javanese language is maintained by raising the children's interest in Javanese cultural such as Javanese song and Javanese radio broadcasting.

\section{CONCLUSIONS AND SUGGESTIONS}

\section{(1) Conclusions}

The study which is concerned with Javanese families language maintenance was aimed at finding the dominant factor affect Javanese language maintenance, the strategies used by Javanese families to maintain their ethnic language, and the reason Javanese families maintain their language. Based on the findings, conclusion are drawn as the following:

1. The factors affect language maintenance by Javanese families in Desa Sambirejo Tmur are : a). Attitude towards Javanese language, b). Value on Javanese language , c). Identity, d). Demography, e). Social factor, and f). Visiting homeland. The dominant factor is attitude towards Javanese language. More over there is the additional factor which reveal during this research, namely visiting homeland.

2. The way Javanese families maintain their language are varies, those are: a). Parents choose Javanese as home language, b). Children mixing Javanese language with Indonesian when speaking to the relatives, c). Parents raising language interest for children by listening some Javanese radio broadcastings, d). Children learn Javanese language since the early age and speak Javanese with the neigborhood, e). Parents motivate the children to concern about the maintenance of Javanese language and culture.

3. Javanese family in Desa Sambirejo Timur relize the responsibility to preserve their Javanese language that resulting the awareness to maintained Javanese language as the identity of Javanese ethnicity.

\section{(2) Sugesstions}

In relation to the conclusion, some constructive points are suggested as the following : 
(1) It is suggested that the parents of Javanese language families in Desa Sambirejo Timur should motivate the children to use Javanese language continually or try to mix Javanese language with Indonesian when speaking to the children.

(2) It is suggested that the Javanese society in Desa Sambirejo Timur should keep the traditional culture of Javanese ethnic and promote it in some ceremonies or celebration such as wedding celebration, independence day, and other cultural celebration to enable the Javanese language and its cultural ethnic become familliar among the younger generation.

\section{REFERENCES}

Bogdan, R.C \& Biklen, S.K. (1992). Qualitative Research for Education. Boston: Allyn and Bacon.

Clyne, M \& Kipp, S. (1999). Pluricentric Languages in an Immigrant Context. Berlin: Mouton de Gruyter.

Coulmas, F. (2013). Sociolinguistics: The Study of Speaker's Choices. US: Cambridge University Press.

Dastgoshadeh, A \& Jalizadah K. (2011). Language Loss, Identity, and English as an International Language. European Journal of Social Science. V.21 (4)

Ferguson, G. (2006). Language Planning and Education. Edinburgh: Edinburgh University Press.

Fishman, J.A. (1991). Reversing Language Shift: theoritical and empirical foundation assistance to threatened languages. Clevedon: Multilingual Matters.

Fishman, J.A. (2000). Can Threatened Language Be Saved? Sydney: Multilingual Mattters.

Filmore, L.W.(2000). Loss of Family Languages: should educator be concerned? Theory into Practice, 39 (4), 203-210. In Carol, LAIYT. (2009). Language Maintenance and Language Loss in First Language. Taipei: National Chengchi University.

Gibson, J \& Ramirez, E. (2004). Maintaining a Minority Language: A Case Study of Hispanic Teenagers. Great Britain: The Cromwell Press.

Hall, J.K. (2012). Teaching and Researching Language and Culture. London: Routledge.

Holmes, J. (2001). An Introduction in Sociolinguistics. Edinburgh: Pearson Education.

Hinton, L. (1999). Involuntary Language Loss Among Immigrants: Asian-American autobiographies. ERIC Digest. Eugene, OR: ERIC Clearinghouse on Educational Management. Retrieved on 31st August 2014 from http://www.cal.org/resources/digest/digestpdfs/9910-hinton-langloss.pdf.

Janse, Mark. (2003). Langauge Death and Langauge Maintenance. Amsterdam: John Benjamins.

Kaplan, R.B \&Baldauf, JR. (1997). Language Planning From Practice to Theory. Great Britain: WBC Book Manufactures. 
Mesthrie, R. (1999). Fifty Ways to Say 'I do': Tracing the Origins of Unstressed do in Cape Flats English. South African Journal of Lingyistics.

Musk, N. (2006). Performing Billingualism in Wales with The Spotlight on Welsh. Linkoping: LiUTryck.

UNESCO. (2003). Language Vitality and Langauge Endangerment: UNESCO ad I Group on Endangered Language Paris.

Sharples, P. (2010). Survey of Attitudes, Values and Beliefs Towards teh Maori Language. New Zealand: Te Puni Kokiri.

Zhang, Donghui. (2008). Between Two Generation: Langauge Maintenance and Acculturation among Chinese Immigrant Family. USA: LFB Scholarly 